\title{
Bunker Cave stalagmites: an archive for central European Holocene climate variability
}

\author{
J. Fohlmeister ${ }^{1}$, A. Schröder-Ritzrau ${ }^{1}$, D. Scholz ${ }^{2}$, C. Spötl ${ }^{3}$, D. F. C. Riechelmann ${ }^{4}$, M. Mudelsee , A. Wackerbarth $^{1}$, \\ A. Gerdes ${ }^{6,7}$, S. Riechelmann ${ }^{8}$, A. Immenhauser ${ }^{8}$, D. K. Richter ${ }^{8}$, and A. Mangini ${ }^{1}$ \\ ${ }^{1}$ Heidelberg Academy of Sciences, Heidelberg, Germany \\ ${ }^{2}$ Institute for Geosciences, University of Mainz, Mainz, Germany \\ ${ }^{3}$ Institute for Geology and Palaeontology, University of Innsbruck, Innsbruck, Austria \\ ${ }^{4}$ Institute for Geography, University of Mainz, Mainz, Germany \\ ${ }^{5}$ Climate Risk Analysis, Hanover, Germany \\ ${ }^{6}$ Institute for Geosciences, Goethe University Frankfurt, Frankfurt, Germany \\ ${ }^{7}$ Department of Earth Sciences, Stellenbosch University, Private Bag X1, Matieland 7602, South Africa \\ ${ }^{8}$ Institute for Geology, Mineralogy and Geophysics, Ruhr-University Bochum, Bochum, Germany
}

Correspondence to: J. Fohlmeister (jens.fohlmeister@iup.uni-heidelberg.de)

Received: 29 March 2012 - Published in Clim. Past Discuss.: 11 May 2012

Revised: 21 September 2012 - Accepted: 3 October 2012 - Published: 31 October 2012

\begin{abstract}
Holocene climate was characterised by variability on multi-centennial to multi-decadal time scales. In central Europe, these fluctuations were most pronounced during winter. Here we present a record of past winter climate variability for the last $10.8 \mathrm{ka}$ based on four speleothems from Bunker Cave, western Germany. Due to its central European location, the cave site is particularly well suited to record changes in precipitation and temperature in response to changes in the North Atlantic realm. We present highresolution records of $\delta^{18} \mathrm{O}, \delta^{13} \mathrm{C}$ values and $\mathrm{Mg} / \mathrm{Ca}$ ratios. Changes in the $\mathrm{Mg} / \mathrm{Ca}$ ratio are attributed to past meteoric precipitation variability. The stable $\mathrm{C}$ isotope composition of the speleothems most likely reflects changes in vegetation and precipitation, and variations in the $\delta^{18} \mathrm{O}$ signal are interpreted as variations in meteoric precipitation and temperature. We found cold and dry periods between 8 and $7 \mathrm{ka}, 6.5$ and $5.5 \mathrm{ka}, 4$ and $3 \mathrm{ka}$ as well as between 0.7 and $0.2 \mathrm{ka}$. The proxy signals in the Bunker Cave stalagmites compare well with other isotope records and, thus, seem representative for central European Holocene climate variability. The prominent $8.2 \mathrm{ka}$ event and the Little Ice Age cold events are both recorded in the Bunker Cave record. However, these events show a contrasting relationship between climate and $\delta^{18} \mathrm{O}$, which is explained by different causes underlying the two climate anomalies. Whereas the Little Ice Age is attributed
\end{abstract}

to a pronounced negative phase of the North Atlantic Oscillation, the $8.2 \mathrm{ka}$ event was triggered by cooler conditions in the North Atlantic due to a slowdown of the thermohaline circulation.

\section{Introduction}

The Holocene represents an epoch of relatively stable, warm climate conditions, particularly in comparison to the large, rapid changes that occurred during the Last Glacial. The largest climate anomaly during the Holocene was the short 8.2 ka cold event (Alley et al., 1997), which has been identified in several climate records (e.g. von Grafenstein et al., 1998; North Greenland Ice Core Project members, 2004; Boch et al., 2009). However, for Europe, several periods during the Holocene with warm/wet and cold/dry climate have been reported (see, for instance, the summaries in Wanner et al., 2008, 2011).

Various archives for terrestrial past climate variability have been evaluated in order to disentangle the complex patterns of Holocene climate change. For instance, numerous studies on tree rings (e.g. Friedrich et al., 1999; Spurk et al., 2002; Büntgen et al., 2010), lake sediments (e.g. Guiot et al., 1993; Magny, 2004; Davis et al., 2003, and references therein) and 
glaciers (e.g. Holzhauser et al., 2005; Joerin et al., 2006; Ivy-Ochs et al., 2009) contributed important information on past Holocene climate variability in Europe. Most of these archives are known to mainly record spring to summer conditions. In contrast, speleothems, and stalagmites in particular, provide the opportunity to reconstruct climate conditions during autumn and winter in central Europe (Wackerbarth et al., 2010). The main reason for this is that enhanced evapotranspiration during spring and summer months leads to reduced infiltration into the karst aquifer. Thus, the major proportion of the drip water feeding the speleothems in most central European caves originates from winter precipitation. In order to gain comprehensive insight into past climate variability, it is important to differentiate between different seasons. For example, Davis et al. (2003) showed in a compilation of European pollen data that temperature variations during the Holocene largely differ between the warm and cold seasons, with larger fluctuations occurring during winter.

Within the last decade, several Holocene climate reconstructions for central Europe based on speleothems have been published (e.g. McDermott et al., 1999; Frisia et al., 2003; Niggemann et al., 2003; Mangini et al., 2005; Vollweiler et al., 2006; Boch et al., 2009). However, none of the currently available speleothem records for central Europe covers the entire Holocene. Here we present a central European composite stalagmite record from Bunker Cave, western Germany, covering the last $10.8 \mathrm{ka}$. We show high-resolution stable $\mathrm{C}$ and $\mathrm{O}$ isotope data as well as $\mathrm{Mg} / \mathrm{Ca}$ ratios. This multiproxy reconstruction enables a robust reconstruction of past winter climate variability in central Europe.

\section{Cave site and methods}

\subsection{Cave site description}

Bunker Cave is located at $51^{\circ} 22^{\prime} 03^{\prime \prime} \mathrm{N}, 7^{\circ} 39^{\prime} 53^{\prime \prime} \mathrm{E}$ in western Germany (Sauerland, Fig. 1) and belongs to a large cave system, which consists of several closely situated caves. The first of these caves, which is located about $13 \mathrm{~m}$ higher than Bunker Cave, was artificially opened in 1860 AD. Bunker Cave itself was discovered in 1926 during road works, and it turned out that both caves are connected. During the Second World War, the entrance area of the cave was artificially enlarged. The entrance to the cave is situated $184 \mathrm{~m}$ above sea level on a south-facing hill slope, and the chambers, where the stalagmites were sampled, are on the same level as the lower entrance. The individual stages of the cave opening probably led to a better ventilation of the cave, resulting in lower $p \mathrm{CO}_{2}$ values of the cave atmosphere. In general, a stronger ventilation may be reflected in an increase in $\delta^{13} \mathrm{C}$ values of speleothem calcite as convincingly demonstrated in a monitoring study by Tremaine et al. (2011). The effect on the $\mathrm{Mg} / \mathrm{Ca}$ ratios and $\delta^{18} \mathrm{O}$ values of speleothem calcite should be much lower. Cave monitoring data show that the ventilation of Bunker Cave has no strong seasonality (Riechelmann et al., 2011), which is ascribed to the two artificial entrances and the horizontal geometry of this part of the cave. Before the cave was opened, gas exchange between the cave interior and the free atmosphere was most likely limited to small fissures at both levels of the cave system resulting in a constant annual ventilation regime similar to today. However, the mean value of cave $p \mathrm{CO}_{2}$ was probably substantially higher.

The cave is developed in Middle to Upper Devonian, low$\mathrm{Mg}$ limestone hosting thin dolomite veins. The thickness of the host rock above the cave ranges from 15 to $30 \mathrm{~m}$, which is covered by up to $70 \mathrm{~cm}$ of soil (inceptisol/alfisol developed from loess loam). Vegetation above the cave consists entirely of C3 plants, i.e. mainly ash and beech as well as scrub vegetation. The mean annual air and water temperature in the cave is about $10.8^{\circ} \mathrm{C}$, and the mean annual amount of precipitation in the area is around $950 \mathrm{~mm} \mathrm{a}^{-1}$ and equally distributed throughout the year. The $\delta^{18} \mathrm{O}$ values of precipitation are between $-6 \%$ (summer months) and $-10 \%$ (winter months). Further cave and monitoring details can be found elsewhere (e.g. Immenhauser et al., 2010; Kluge et al., 2010; Riechelmann et al., 2011; Münsterer et al., 2012).

Four speleothems, which grew within a maximum distance of $12 \mathrm{~m}$ from each other, were removed from the cave for this study (Bu1, Bu2, Bu4 and Bu6). Stalagmite Bu1 has a length of about $65 \mathrm{~cm}$. Bu2 and Bu4 are approximately $20 \mathrm{~cm}$ long, whereas Bu6 is a flowstone with a length of about $6 \mathrm{~cm}$ (Fig. 1). All stalagmites have a diameter of about 5 to $10 \mathrm{~cm}$ and were sampled under actively dripping sites. The drip sites of the investigated stalagmites have been monitored within the framework of a comprehensive, long-term cave monitoring program (Riechelmann et al., 2011). The $\delta^{18} \mathrm{O}$ values of the drip water show that the recharge water is well mixed within the aquifer and corresponds to the infiltration weighted annual mean $\delta^{18} \mathrm{O}$ value of precipitation, which is approximately $-8.1 \%$ (Wackerbarth et al., 2010; Riechelmann et al., 2011). In stable isotope equilibrium, we would expect the $\delta^{18} \mathrm{O}$ value of the precipitated calcite to be about $-7.4 \%$ under present-day conditions (applying the fractionation factor of Kim and O'Neil, 1997). However, experiments with recent calcite precipitates reveal that the $\delta^{18} \mathrm{O}$ value is between -5.6 and $-6.3 \%$ o (Riechelmann et al., 2012). This discrepancy is explained by isotopic disequilibrium during calcite precipitation.

\subsection{Methods}

\subsubsection{Th/U dating}

Samples for $\mathrm{Th} / \mathrm{U}$-dating were cut from the growth axis of the stalagmites using a diamond-coated band saw. The thickness (in growth direction) of individual samples is typically $4 \mathrm{~mm}$. All samples were analysed by thermal ionisation 


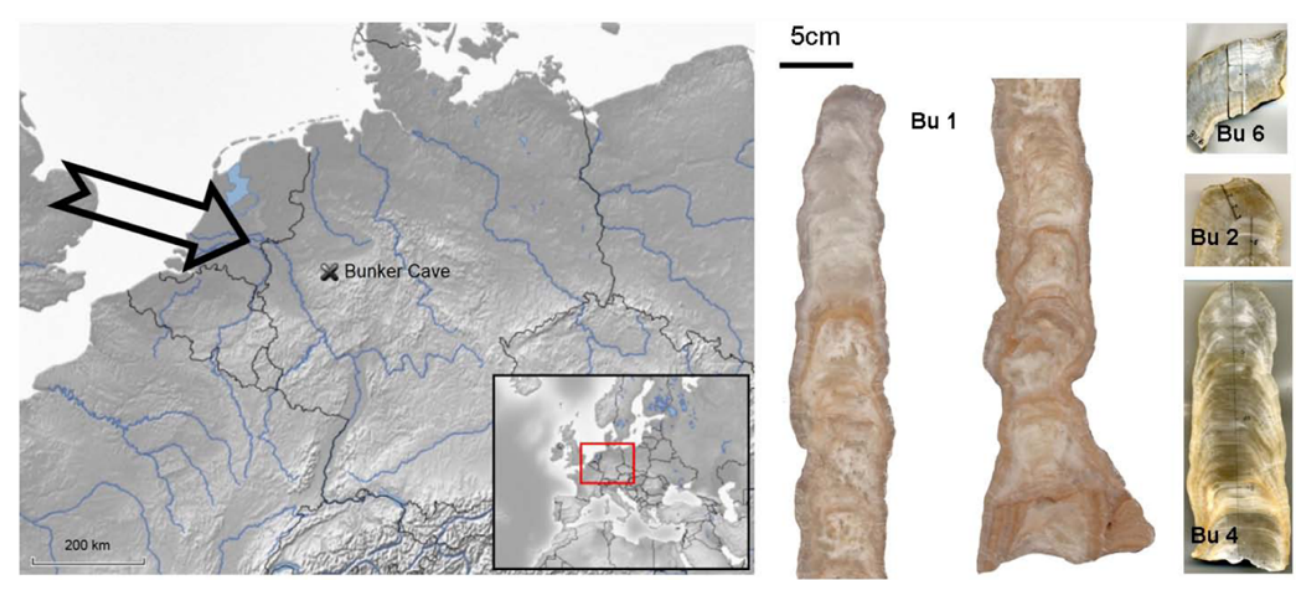

Fig. 1. Map of central Europe showing the location of Bunker Cave. Central Europe is strongly influenced by the westerly wind system (indicated by the black solid arrow). The four studied stalagmites from Bunker Cave are shown on the right. For Bu2, only the Holocene part of the sample is shown.

mass spectrometry (TIMS) at the Heidelberg Academy of Sciences. Methods used for sample preparation and mass spectrometric analysis are explained in detail in Frank et al. (2000) and Holzkämper et al. (2005). The calibration of the $\mathrm{U}$ and Th spikes is described in Hoffmann et al. (2007). Due to the relatively low $\mathrm{U}$ content of the samples, Th/Udating of Holocene speleothems from Bunker Cave using the TIMS method is challenging. Therefore, a Th solution with precisely determined concentration and isotopic composition was added to some sub-samples in order to increase the analysis time for Th and to improve counting statistics. The measured isotope ratios were corrected accordingly, and the uncertainties in concentration and isotope composition of the added Th solution were propagated to the final age errors. Ages were calculated using the half lives of Cheng et al. (2000). Correction for detrital contamination assumes a ${ }^{232} \mathrm{Th} /{ }^{238} \mathrm{U}$ concentration ratio of $3.8 \pm 1.9$ and ${ }^{230} \mathrm{Th},{ }^{234} \mathrm{U}$ and ${ }^{238} \mathrm{U}$ in secular equilibrium. Age uncertainties are quoted at the 2- $\sigma$ level and do not include half-life uncertainties. The reference year for all ages given in the study is $1950 \mathrm{AD}$.

\subsubsection{Radiocarbon dating}

Samples for radiocarbon dating were drilled in a $\mathrm{CO}_{2}$-free atmosphere in the Heidelberg radiocarbon laboratory using a hand-held dental drill with a burr diameter of $1 \mathrm{~mm}$. Sub-samples from the very top of the stalagmites were milled from the stalagmite surface. The uppermost layers $(\sim 100 \mu \mathrm{m})$ of the stalagmite, which may be contaminated due to exchange with atmospheric carbon, were not used for analysis. The $\mathrm{CaCO}_{3}$ powder was acidified $(\mathrm{HCl})$ in vacuo, and the resulting $\mathrm{CO}_{2}$ was combusted with $\mathrm{H}_{2}$ to $\mathrm{C}$ on a $\mathrm{Fe}$ catalyst at $575^{\circ} \mathrm{C}$. The samples were measured at the MICADAS at ETH Zurich (Synal et al., 2007).

\subsection{3 $\quad \delta^{13} \mathrm{C}$ and $\delta^{18} \mathrm{O}$ analysis}

The stalagmites were micro-milled continuously along the growth axis at increments of $0.3 \mathrm{~mm}$ for Bu1 and Bu6, $0.2 \mathrm{~mm}$ for $\mathrm{Bu} 4$ and $0.15 \mathrm{~mm}$ for Bu2. Stable $\mathrm{C}$ and $\mathrm{O}$ isotopes were measured at the triple collector gas source isotope ratio mass spectrometer of the University of Innsbruck. The mass spectrometer is linked to an on-line, automated carbonate preparation system (for details, see Spötl and Mattey, 2006). Isotope ratios are reported against the VPDB scale, and the $1 \sigma$ precision is 0.06 and $0.08 \%$ for $\delta^{13} \mathrm{C}$ and $\delta^{18} \mathrm{O}$, respectively.

\subsubsection{Magnesium and calcium analyses}

The stalagmites were cut along the growth axis into 2-cmlong pieces, which were mounted in epoxy resin discs and polished. $\mathrm{Mg} / \mathrm{Ca}$ ratios were measured parallel to the growth axis. The continuous profile is located within $2 \mathrm{~mm}$ of the stable isotope track. $\mathrm{Mg} / \mathrm{Ca}$ ratios of the speleothems were measured by Laser Ablation ICP-MS (LA-ICPMS) at the Mineralogical Institute, Frankfurt, Germany, using a New Wave UP213 ultraviolet laser system, coupled to a ThermoFinnigan Element II sector field ICP-MS (Gerdes and Zeh, 2006). Element data were continuously acquired using a $60 \mu \mathrm{m}$ circular ablation spot and a scan speed of $10 \mu \mathrm{m} \mathrm{s}^{-1}$. The method produces approximately 40 data points per $\mathrm{mm}$ corresponding to a spatial resolution of $25 \mu \mathrm{m}$. Background counts, measured with the laser in off mode, were subtracted from the raw data. All data are normalized to the $\mathrm{Ca}$ content of the calcite and standardized against NIST 612 glass (Pearce et al., 1996), which was measured before and after each sample. A continuous sample scan had a maximum length of $2 \mathrm{~cm}$. 


\subsubsection{Microscopy}

Thin sections were made from all four stalagmites by sawing a thin slice near the growth axis, next to the element track, which were broken into approximately 4-cm-long pieces in order to obtain a continuous series of thin sections. These pieces were stuck on small glass plates and polished to $30 \mu \mathrm{m}$ thickness. These thin sections were examined using standard transmitted-light microscopy as well as using a hot cathodeCL-microscope (type Lumic HC1-LM; Neuser et al., 1995).

\section{Results}

\subsection{Th/U-dating and microscopic analysis}

Ten sub-samples from stalagmite $\mathrm{Bu} 1$, four sub-samples from $\mathrm{Bu} 2$, eleven sub-samples from $\mathrm{Bu} 4$ and three subsamples from Bu6 were dated (Table 1). Dating of the samples was challenging due to the relatively low $\mathrm{U}$ content $(\sim 0.1 \mathrm{ppm})$. The $2 \sigma$-age uncertainty is between 100 and 300 a for most samples (Table 1). Some samples contain elevated amounts of detritial Th (between 2 and $3 \mathrm{ng} \mathrm{g}^{-1}$, Table 1) leading to significant age corrections. Stalagmite Bu6 covers the period between 10.7 and $8.8 \mathrm{kaBP}$, and the Holocene part of $\mathrm{Bu} 2$ (i.e. the upper $7 \mathrm{~cm}$ ) grew between 10.7 and $7.7 \mathrm{ka} \mathrm{BP}$. Bu4 covers the last approximately $8.1 \mathrm{ka}$ (Fig. 2). Thin sections revealed that Bu4 is dominated by columnar crystals, which indicates relatively slow and constant growth rates. Two small detritus layers were observed at about 15 and $17 \mathrm{~cm}$ distance from top (dft), which are identified as coralloid layers (Fig. 3b). These layers probably reflect periods of limited growth, which, however, seem to have been short since $\mathrm{Th} / \mathrm{U}$ dating does not resolve a growth stop. Petrographic investigation of Bu1 shows at approximately $17 \mathrm{~cm}$ dft a detritus-rich layer revealing a hiatus. The duration of this interruption of stalagmite growth cannot be determined precisely due to unreliable $\mathrm{Th} / \mathrm{U}$ dates in the interval between 14.6 and $30 \mathrm{~cm}$ dft. Hence, age data for Bu1 are only presented between the top and $14 \mathrm{~cm}$ dft as well as from 31 to $49 \mathrm{~cm}$ dft including the periods between "pre-modern" (Sect. 3.2) and 1.6 ka BP as well as 4.7 and $6.7 \mathrm{ka} \mathrm{BP} \mathrm{(Fig.} \mathrm{2).}$ During the latter period Bul consists mainly of fast growing dendritic crystals, in agreement with the growth rate derived from the age measurements. In the section below $\sim 49 \mathrm{~cm}$ $\mathrm{dft}$, it was again impossible to measure reliable dates. The bottom section of Bu1 $(\sim 10 \mathrm{~cm})$ grew during the Eemian. Thin section analysis of the top of $\mathrm{Bu} 2$ and $\mathrm{Bu} 6$ indicates brown layers, which are interpreted as detrital layers highlighting hiatuses. Hence, data for the upper $7(\mathrm{Bu} 2)$ and $2 \mathrm{~mm}$ (Bu6) were discarded. The other parts of $\mathrm{Bu} 2$ and $\mathrm{Bu} 6$ as well as the younger part of Bu1 are solely formed of columnar crystals (Fig. 3b), which reveal relatively slow and constant growth rates.

\subsection{Radiocarbon}

Three radiocarbon analyses were performed at the top sections of stalagmite $\mathrm{Bu} 4$ and $\mathrm{Bu} 1$. This enabled to test whether the stalagmites stopped growing before or after the atmospheric radiocarbon anomaly in the middle of the 20th century (e.g. Levin and Kromer, 2004; Hua and Barbetti, 2004). Due to the low $\mathrm{U}$ content (Table 1 ), the $\mathrm{Th} / \mathrm{U}$ age data are not precise enough to verify/falsify recent speleothem growth. Bu1 does not show a clear bomb-peak, whereas Bu4 reveals a typical increase and decrease in its uppermost $2 \mathrm{~mm}$ as expected for the radiocarbon bomb-pulse captured in stalagmites (see e.g. Genty and Massault, 1999; Mattey et al., 2008; Fohlmeister et al., 2011, Table 2). This suggests that $\mathrm{Bu} 4$ was actively growing until its removal, whereas Bu1 definitely stopped growing before $1950 \mathrm{AD}$.

\subsection{Chronology}

The growth phases of all four stalagmites cover the last $10.8 \mathrm{ka}$. During several intervals, two stalagmites grew contemporaneously (i.e. from 0 to $1.6 \mathrm{ka}$; from 4.7 to $6.7 \mathrm{ka}$; from 7.7 to $8.1 \mathrm{ka}$ and between 8.8 and $10.7 \mathrm{ka}$, Fig. 2). Thus, it is possible to test whether the proxy signals recorded in individual stalagmites are reproducible. If this is the case, a dominant influence of local, drip-site specific effects can be ruled out, and the proxy signals likely reflect past climate variability. The temporally overlapping sections allow us to assemble a composite record. We a priori assume that the $\delta^{18} \mathrm{O}$ records of the four stalagmites represent one common signal. The records are combined with iscam (intra-site correlation age modelling; Fohlmeister, 2012). This method correlates dated proxy signals from several stalagmites, determines the most probable age-depth model and calculates the age uncertainty for the combined record. Iscam can be used to quantitatively verify whether signals from two individual stalagmites have a common signal within the age errors. Furthermore, the algorithm is able to prove whether the resulting correlation is statistically significant. This provides the advantage of enlarging the signal-to-noise ratio and minimising the age uncertainties within the overlapping periods. In addition, iscam can be used to test if the signals of two archives correlate above significance limits, which indicate that the observed variations have a common cause.

For age-depth modelling, both the $\mathrm{Th} / \mathrm{U}$ ages and the radiocarbon measurements are used. The ${ }^{14} \mathrm{C}$ measurements of $\mathrm{Bu} 4$ show a typical bomb-peak as expected from speleothem calcite precipitated during the last $60 \mathrm{a}$. An additional constraint is given by the observation that the drip water from the corresponding active drip site is supersaturated with respect to calcite. This indicates that under present-day conditions calcite can be precipitated. Both findings provide us a tie point, and we conservatively prescribed the top age of $\mathrm{Bu} 4$ to be $1997 \mathrm{AD} \pm 10$ a for the age-depth modelling (Bu4 was removed in $2007 \mathrm{AD}$ ). For the top of $\mathrm{Bu} 1$, the ${ }^{14} \mathrm{C}$ bomb peak 
Table 1. Uranium and thorium isotopic compositions and ${ }^{230} \mathrm{Th}$ ages for Bunker Cave stalagmites Bu1, Bu2, Bu4 and Bu6 measured by TIMS. Errors are $2 \sigma$ analytical errors. Corrected ${ }^{230} \mathrm{Th}$ ages assume an initial ${ }^{230} \mathrm{Th} /{ }^{232} \mathrm{Th}$ concentration ratio of $3.8 \pm 1.9$. Samples marked by an asterisk indicate addition of extra Th (see Sect. 2.2).

\begin{tabular}{|c|c|c|c|c|c|c|}
\hline Sample ID & $\begin{array}{l}{ }^{238} \mathrm{U} \\
{[\mathrm{ppb}]}\end{array}$ & $\begin{array}{l}{ }^{232} \mathrm{Th} \\
{[\mathrm{ppt}]}\end{array}$ & $\begin{array}{l}\delta^{234} \mathrm{U} \\
{[\% \circ]}\end{array}$ & $\begin{array}{l}\left({ }^{230} \mathrm{Th} /{ }^{238} \mathrm{U}\right) \\
\text { act. ratio }\end{array}$ & $\begin{array}{l}\text { age }_{\text {uncorrected }} \\
{[\mathrm{ka} \mathrm{BP}]}\end{array}$ & $\begin{array}{l}\text { age }_{\text {corrected }} \\
{[\mathrm{ka} \mathrm{BP}]}\end{array}$ \\
\hline \multicolumn{7}{|l|}{$\mathrm{Bu} 1$} \\
\hline $\mathrm{Bu} 1-2 \mathrm{~cm}$ & $44.4 \pm 0.1$ & $36 \pm 2$ & $390 \pm 11$ & $0.0078 \pm 0.0027$ & $0.57 \pm 0.21$ & $0.56 \pm 0.21$ \\
\hline $\mathrm{Bu} 1-3.3 \mathrm{~cm}^{*}$ & $48.08 \pm 0.1$ & $274 \pm 29$ & $354 \pm 10$ & $0.0082 \pm 0.0023$ & $0.72 \pm 0.18$ & $0.60 \pm 0.20$ \\
\hline Bu1-9 cm & $58.5 \pm 0.1$ & $57 \pm 1$ & $332 \pm 8$ & $0.0139 \pm 0.0017$ & $1.11 \pm 0.14$ & $1.09 \pm 0.14$ \\
\hline Bu1-14 cm & $39.8 \pm 0.1$ & $74 \pm 1$ & $336 \pm 8$ & $0.0193 \pm 0.0019$ & $1.57 \pm 0.16$ & $1.53 \pm 0.16$ \\
\hline Bu1-31 cm & $61.5 \pm 0.1$ & $1004 \pm 8$ & $292 \pm 4$ & $0.0547 \pm 0.0052$ & $5.02 \pm 0.46$ & $4.66 \pm 0.48$ \\
\hline $\mathrm{Bu} 1-35 \mathrm{~cm}$ & $60.4 \pm 0.1$ & $1403 \pm 8$ & $283 \pm 5$ & $0.0581 \pm 0.0014$ & $5.50 \pm 0.13$ & $4.98 \pm 0.30$ \\
\hline Bu1-39.5 cm & $68.6 \pm 0.1$ & $661 \pm 4$ & $252 \pm 9$ & $0.0653 \pm 0.0026$ & $6.00 \pm 0.25$ & $5.78 \pm 0.28$ \\
\hline $\mathrm{Bu} 1-42 \mathrm{~cm}$ & $84.6 \pm 0.1$ & $1317 \pm 6$ & $287 \pm 4$ & $0.0737 \pm 0.0025$ & $6.70 \pm 0.23$ & $6.36 \pm 0.29$ \\
\hline Bu1-46 cm & $90.7 \pm 0.2$ & $100 \pm 1$ & $278 \pm 6$ & $0.0735 \pm 0.0017$ & $6.42 \pm 0.16$ & $6.40 \pm 0.15$ \\
\hline $\mathrm{Bu} 1-49 \mathrm{~cm}$ & $120.6 \pm 0.1$ & $891 \pm 8$ & $271 \pm 6$ & $0.0759 \pm 0.0065$ & $6.81 \pm 0.59$ & $6.64 \pm 0.59$ \\
\hline \multicolumn{7}{|l|}{$\mathrm{Bu} 2$} \\
\hline $\mathrm{Bu} 2-1 \mathrm{~cm}$ & $57.1 \pm 0.1$ & $2099 \pm 19$ & $440 \pm 9$ & $0.0989 \pm 0.0029$ & $8.39 \pm 0.25$ & $7.66 \pm 0.46$ \\
\hline $\mathrm{Bu} 2-4 \mathrm{~cm}$ & $116.6 \pm 0.2$ & $221 \pm 3$ & $437 \pm 7$ & $0.1174 \pm 0.0033$ & $9.24 \pm 0.27$ & $9.20 \pm 0.27$ \\
\hline $\mathrm{Bu} 2-5.5 \mathrm{~cm}$ & $135.9 \pm 0.1$ & $597 \pm 3$ & $442 \pm 5$ & $0.1288 \pm 0.0021$ & $10.20 \pm 0.18$ & $10.11 \pm 0.18$ \\
\hline $\mathrm{Bu} 2-7 \mathrm{~cm}$ & $191.6 \pm 0.2$ & $304 \pm 2$ & $564 \pm 4$ & $0.1469 \pm 0.0025$ & $10.68 \pm 0.19$ & $10.65 \pm 0.19$ \\
\hline \multicolumn{7}{|l|}{ Bu4 } \\
\hline Bu4-1.45 cm* & $66 \pm 0.1$ & $54 \pm 33$ & $662 \pm 24$ & $0.0135 \pm 0.0022$ & $0.85 \pm 0.15$ & $0.83 \pm 0.15$ \\
\hline $\mathrm{Bu} 4-3 \mathrm{~cm}$ & $79.5 \pm 0.2$ & $47 \pm 0$ & $501 \pm 7$ & $0.0157 \pm 0.0019$ & $1.10 \pm 0.14$ & $1.09 \pm 0.14$ \\
\hline $\mathrm{Bu} 4-5.5 \mathrm{~cm}$ & $75.4 \pm 0.2$ & $1881 \pm 9$ & $514 \pm 7$ & $0.0204 \pm 0.0011$ & $1.89 \pm 0.08$ & $1.42 \pm 0.26$ \\
\hline $\mathrm{Bu} 4-7 \mathrm{~cm}$ & $72.0 \pm 0.1$ & $590 \pm 4$ & $548 \pm 7$ & $0.0256 \pm 0.0020$ & $1.91 \pm 0.14$ & $1.76 \pm 0.16$ \\
\hline Bu4-9 cm & $68.6 \pm 0.1$ & $227 \pm 2$ & $582 \pm 8$ & $0.0361 \pm 0.0018$ & $2.52 \pm 0.13$ & $2.46 \pm 0.13$ \\
\hline Bu4-10.15 cm* & $57.7 \pm 0.1$ & $592 \pm 31$ & $558 \pm 10$ & $0.0480 \pm 0.0022$ & $3.53 \pm 0.16$ & $3.35 \pm 0.19$ \\
\hline Bu4-12 cm & $95.8 \pm 0.2$ & $390 \pm 2$ & $598 \pm 7$ & $0.0569 \pm 0.0021$ & $3.96 \pm 0.15$ & $3.89 \pm 0.16$ \\
\hline Bu4-13.6 cm* & $102.9 \pm 0.2$ & $1038 \pm 27$ & $587 \pm 7$ & $0.0724 \pm 0.0016$ & $5.20 \pm 0.11$ & $5.02 \pm 0.15$ \\
\hline $\mathrm{Bu} 4-15.1 \mathrm{~cm}^{*}$ & $69.1 \pm 0.1$ & $2019 \pm 27$ & $664 \pm 7$ & $0.0888 \pm 0.0034$ & $6.39 \pm 0.24$ & $5.89 \pm 0.36$ \\
\hline Bu4-17.1 cm* & $69 \pm 0.1$ & $1200 \pm 41$ & $600 \pm 10$ & $0.1027 \pm 0.0051$ & $7.45 \pm 0.37$ & $7.14 \pm 0.41$ \\
\hline Bu4-19.25 cm* & $84.1 \pm 0.2$ & $368 \pm 30$ & $537 \pm 9$ & $0.1103 \pm 0.0029$ & $8.11 \pm 0.22$ & $8.03 \pm 0.23$ \\
\hline \multicolumn{7}{|l|}{ Bu6 } \\
\hline Bu6-0.8 cm & $219.1 \pm 0.4$ & $1437 \pm 8$ & $277 \pm 4$ & $0.0996 \pm 0.0017$ & $8.93 \pm 0.16$ & $8.78 \pm 0.18$ \\
\hline Bu6-2.5 cm & $199.4 \pm 0.4$ & $333 \pm 2$ & $271 \pm 5$ & $0.1127 \pm 0.0018$ & $10.08 \pm 0.18$ & $10.04 \pm 0.18$ \\
\hline Bu6-3.8 cm & $237.0 \pm 0.5$ & $2779 \pm 14$ & $275 \pm 6$ & $0.1190 \pm 0.0032$ & $10.86 \pm 0.30$ & $10.59 \pm 0.34$ \\
\hline
\end{tabular}

is not visible. Thus, the stalagmite definitely stopped growing before $1950 \mathrm{AD}$. In addition, the strong increase in $\delta^{13} \mathrm{C}$ values observed for Bu4 is not present in Bu1 (Sect. 3.4, Fig. 3) suggesting that $\mathrm{Bu} 1$ stopped growing prior to the $\delta^{13} \mathrm{C}$ increase. In order to provide iscam the possibility to define the timing of the growth stop appropriately, we prescribed that the top section of Bu1 ceased growing around $100 \mathrm{a} \mathrm{BP}$ and included a large uncertainty of $40 \mathrm{a}$.

Iscam uses the available age information (means and errors) and the variation in the $\delta^{18} \mathrm{O}$ signal of the four stalagmites in order to obtain the best age-depth model. For a detailed description of the method, the reader is referred to the original publication (Fohlmeister, 2012). Usually, the age uncertainties in the overlapping periods are smaller than in the periods without overlaps (Fig. 2). Hence, jumps in the uncertainty range may occur at transitions between overlapping and non-overlapping parts. In the non-overlapping parts of the stalagmites, the age-depth models are constructed by linear interpolation between dated depths. The shaded areas of the overlapping periods between $\mathrm{Bu} 4$ and $\mathrm{Bu} 2$ as well as between $\mathrm{Bu} 2$ and $\mathrm{Bu} 6$ represent $68 \%$ confidence intervals. The correlation coefficient of the according $\delta^{18} \mathrm{O}$ time series does not exceed the $95 \%$ threshold. The threshold to the $95 \%$ interval for the correlation coefficient between $\mathrm{Bu} 2$ and Bu6 is only missed by 0.01 . The reason for missing the $95 \%$ interval range between $\mathrm{Bu} 2$ and $\mathrm{Bu} 4$ is related to the relatively short overlapping interval between both stalagmites (Fohlmeister, 2012). 
Table 2. ${ }^{14} \mathrm{C}$ activity of the top sections from stalagmites Bu1 and $\mathrm{Bu} 4$.

\begin{tabular}{lllrr}
\hline $\begin{array}{l}\text { Sample } \\
\text { name }\end{array}$ & $\begin{array}{l}\text { Depth } \\
{[\mathrm{mm}]}\end{array}$ & $\begin{array}{l}\text { HD analysis } \\
\text { number }\end{array}$ & $\begin{array}{r}{ }^{14} \mathrm{C} \text { activity } \\
{[\mathrm{pmC}]}\end{array}$ & $\begin{array}{r}1 \sigma \text { error } \\
{[\mathrm{pmC}]}\end{array}$ \\
\hline Bu1 xix & $0.1 \pm 0.1$ & 29116 & 91.35 & 0.25 \\
Bu1 xx & $0.5 \pm 0.3$ & 29117 & 91.81 & 0.24 \\
Bu1 x & $1.0 \pm 0.5$ & 26607 & 91.14 & 0.25 \\
\hline Bu4 Top & $0.05 \pm 0.05$ & 28403 & 97.44 & 0.27 \\
Bu4 1 mm & $0.6 \pm 0.5$ & 28404 & 100.15 & 0.26 \\
Bu4 2 mm & $1.6 \pm 0.5$ & 28405 & 87.83 & 0.23 \\
\hline
\end{tabular}

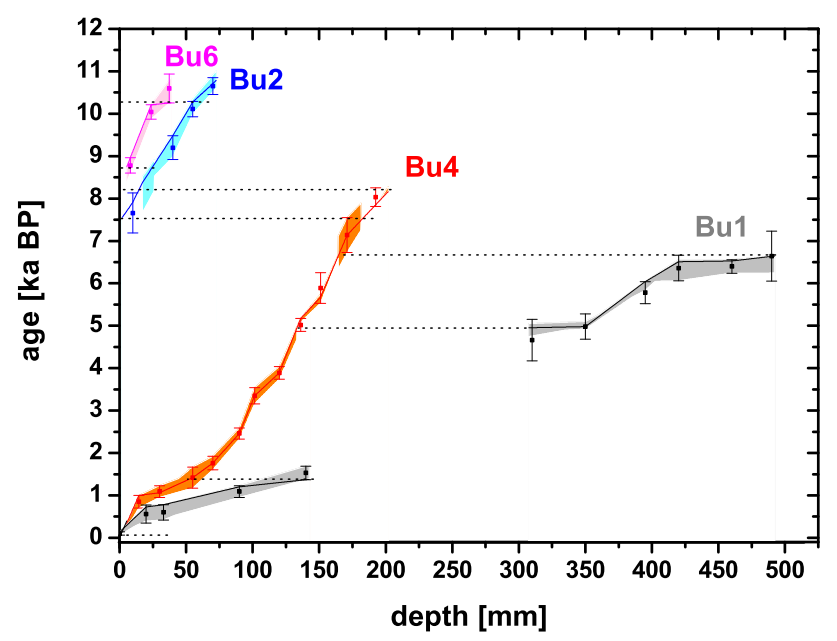

Fig. 2. Th/U ages (solid squares) and associated $2 \sigma$-uncertainties as well as the age-depth models (solid line) for the four stalagmites calculated using iscam (Fohlmeister, 2012). The shaded areas define the $2 \sigma$-uncertainty range. The thin dotted lines denote periods that are contained in two stalagmites (i.e. overlapping sections).

\section{$3.4 \delta^{13} \mathrm{C}, \delta^{18} \mathrm{O}$ and $\mathrm{Mg} / \mathrm{Ca}$ time series}

Given that the spatial resolution of the $\mathrm{Mg} / \mathrm{Ca}$ elemental ratios exceeds that of the carbon and oxygen isotope record, the elemental proxy has been brought to the resolution of the $\delta^{13} \mathrm{C}$ and $\delta^{18} \mathrm{O}$ records. For this purpose, all $\mathrm{Mg} / \mathrm{Ca}$ ratios within the depth range of one stable isotope sample have been averaged. The $\mathrm{Mg} / \mathrm{Ca}$ data (Fig. 3a) show a decreasing trend within the last $10.8 \mathrm{ka}$. During the early Holocene, $\mathrm{Mg} / \mathrm{Ca}$ ratios are approximately twice as high as in the recent period, 0.0033 and 0.0015 , respectively. Both the absolute $\mathrm{Mg} / \mathrm{Ca}$ values and the pattern are similar in overlapping parts of $\mathrm{Bu} 2, \mathrm{Bu} 4$ and $\mathrm{Bu} 6$ suggesting that all three stalagmites experienced comparable hydrological conditions in agreement with findings from present-day cave monitoring (Riechelmann et al., 2011). The $\mathrm{Mg} / \mathrm{Ca}$ ratio of Bu6 is slightly lower than that of Bu2. Stalagmite Bu1 shows significantly lower

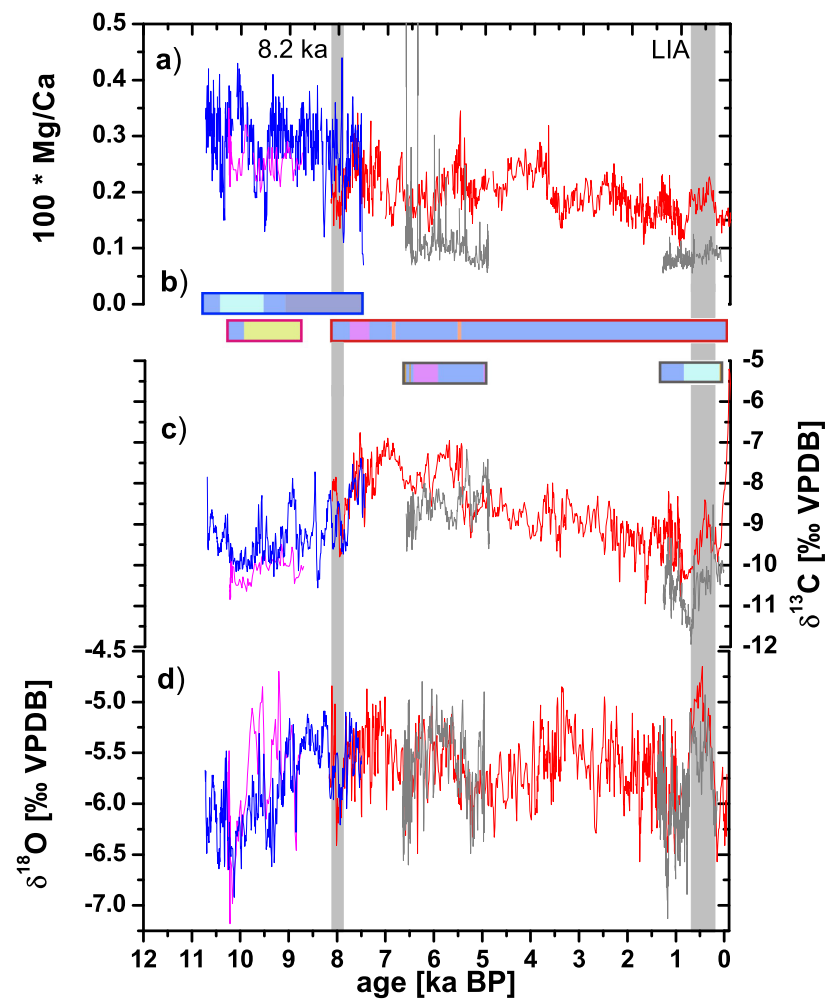

Fig. 3. Time series of $\mathrm{Mg} / \mathrm{Ca}$ (a), petrographic $\operatorname{logs}(\mathbf{b}), \delta^{13} \mathrm{C}$ (c) and $\delta^{18} \mathrm{O}$ (d) for Bu1 (grey), Bu4 (red), Bu2 (blue) and Bu6 (magenta). The vertical light grey lines represent large-scale European cold events (i.e. the $8.2 \mathrm{ka}$ event, $8.2 \mathrm{ka}$, and the Little Ice Age, LIA). Colour codes for the different crystallographic fabrics are the following: blue: columnar; grey: elongated columnar; aqua: short columnar; yellow: open columnar; pink: dendritic; orange: coralloids and/or detrital layers.

values than Bu4. Similarly, the $\mathrm{Mg} / \mathrm{Ca}$ patterns of $\mathrm{Bu} 1$ and $\mathrm{Bu} 4$ are - apart from the generally decreasing trend - different (Fig. 3a).

The total range of the $\delta^{13} \mathrm{C}$ values of the four Bunker Cave stalagmites is between -12 and $-5 \%$ (Fig. 3c). In the early Holocene, $\mathrm{Bu} 2$ and $\mathrm{Bu} 6$ show $\delta^{13} \mathrm{C}$ values between -9 and $-10 \%$. As for $\mathrm{Mg} / \mathrm{Ca}$, the values of $\mathrm{Bu} 6$ are lower than those of Bu2. The $\delta^{13} \mathrm{C}$ values of Bu2 increase between 8.5 and $7.5 \mathrm{ka}$, which is in agreement with the $\mathrm{Bu} 4$ record. The $\delta^{13} \mathrm{C}$ values of the four Bunker stalagmites show maximum values about $-7 \%$ o between 8 and $6 \mathrm{ka}$. After $6 \mathrm{ka}$, the $\delta^{13} \mathrm{C}$ values of $\mathrm{Bu} 4$ decrease. In the recent past, $\mathrm{Bu} 4$ has shown a steep increase by about $4 \%$ in $\delta^{13} \mathrm{C}$. Bu1 generally shows the same pattern as Bu4, especially in the young section of the two stalagmites. However, the $\delta^{13} \mathrm{C}$ values of $\mathrm{Bu} 1$ are lower compared to those of Bu4. Furthermore, the rapid increase measured in the recent part of $\mathrm{Bu} 4$ is not visible in $\mathrm{Bu} 1$ (Fig. 3c) confirming that Bu1 stopped growing before this anomaly occurred. 
The $\delta^{18} \mathrm{O}$ values were used to determine the age model for the composite record. Therefore, the $\delta^{18} \mathrm{O}$ records in overlapping parts of different stalagmites are in agreement (Fig. 3d). The high correlation coefficients ( 0.9 for the young parts of Bu1 and Bu4, 0.79 for the old parts of Bu1 and Bu4, 0.72 for $\mathrm{Bu} 2$ and $\mathrm{Bu} 4$ and 0.76 for $\mathrm{Bu} 2$ and $\mathrm{Bu} 6$ ) strongly suggest that the $\delta^{18} \mathrm{O}$ values reflect climate conditions above Bunker Cave rather than site-specific effects. This is also supported by the similar absolute $\delta^{18} \mathrm{O}$ values of all four stalagmites. $\delta^{18} \mathrm{O}$ variability during the last $10.8 \mathrm{ka}$ is in the range of $2 \%$, with the highest values observed at $0.5 \mathrm{ka}$ $(-5 \%)$ and the lowest values $(-7 \%$ ) recorded around $10 \mathrm{ka}$ (Fig. 3d).

\section{Discussion}

\section{1 $\mathrm{Mg} / \mathrm{Ca}$ ratios}

Previous work suggested that the speleothem calcite $\mathrm{Mg} / \mathrm{Ca}$ ratio is a qualitative proxy for the amount of precipitation above the cave or infiltration into the karst aquifer (see Fairchild and Treble, 2009, and citations therein). Regarding the $\mathrm{Mg} / \mathrm{Ca}$ records from Bunker Cave, first, an explanation approach for the long-term decreasing trend in the $\mathrm{Mg} / \mathrm{Ca}$ ratio of the stalagmites Bu2 and Bu4 during the Early to Middle Holocene (Fig. 3a) is required. For this purpose, possible variations of the drip water sources feeding the stalagmite must be considered.

Modern rain water at the cave location, collected in a rain gauge (DIN 58666C), has a negligible Ca concentration (long-term mean $0.9 \mathrm{mgl}^{-1}$ ) and a mean $\mathrm{Mg} / \mathrm{Ca}$ ratio of $0.2 \pm 0.1$ (Riechelmann et al., 2011). Water in the upper soil zone above Bunker Cave has a low Ca concentration and a $\mathrm{Mg} / \mathrm{Ca}$ ratio of $0.13 \pm 0.01$. This is related to weathering of the soil clay minerals, such as Mg-bearing chlorite, montmorillonite and illite. Weathering of this siliceous soil material is also documented in seasonal changes in drip water $\mathrm{Mg}$ isotope values (Riechelmann et al., 2012). During percolation through the low Mg Devonian limestone, which hosts thin dolomite veins, the water dissolves the host rock with, on average, lower $\mathrm{Mg} / \mathrm{Ca}$ ratios than the soil water $(\mathrm{Mg} / \mathrm{Ca}$ : 0.004 $0.008, n=5$ ). The resulting drip water feeding the stalagmite represents therefore a mixture of the $\mathrm{Mg} / \mathrm{Ca}$ ratios of meteoric precipitation, soil zone clay content and host rock carbonate resulting in a $\mathrm{Mg} / \mathrm{Ca}$ ratio of the drip water of 0.02 0.06 (Riechelmann et al., 2011). During the Last Glacial period, loess was deposited above Bunker Cave (von Kamp and Ribbert, 2005). This loess may have had a higher $\mathrm{Mg} / \mathrm{Ca}$ ratio. Weathering and leaching during the transition and the Early Holocene removed some of the $\mathrm{Mg}$-bearing loess cover and may have resulted in relatively high $\mathrm{Mg} / \mathrm{Ca}$ ratios in the stalagmites during the Early Holocene. Progressive weathering and decalcification may have led to elution of the initially high $\mathrm{Mg}$ components of the aeolian deposits causing $\mathrm{Mg} / \mathrm{Ca}$ ratios in the stalagmite to decrease. This may coincide with enhanced weathering in the Atlantic stage as postulated by Richter et al. (2004). We want to emphasize that we do not know if the $\mathrm{Mg} / \mathrm{Ca}$ ratio of the loess was indeed higher than that of the Devonian host rock. However, this is currently the only explanation for the observed trend in the $\mathrm{Mg} / \mathrm{Ca}$ ratio.

Short-term variations in $\mathrm{Mg} / \mathrm{Ca}$ ratios are attributed to the amount of precipitation or infiltration. The extensive longterm monitoring at Bunker Cave (Riechelmann et al., 2011) reveals that a major process affecting the $\mathrm{Mg} / \mathrm{Ca}$ ratio in stalagmites is prior calcite precipitation (PCP), i.e. calcite that precipitates before the solution reaches the stalagmite. Lower infiltration into the karst aquifer leads to a higher proportion of air compared to water in the host rock favouring degassing of $\mathrm{CO}_{2}$ and, thus, PCP. Lower rainfall amounts also lead to lower drip rates and, thus, more PCP at the cave ceiling. In both cases, the $\mathrm{Mg} / \mathrm{Ca}$ ratio in the stalagmites should increase as has been demonstrated in various studies (Tooth and Fairchild, 2003; Cruz Jr. et al., 2007). The effect of PCP on the $\mathrm{Mg} / \mathrm{Ca}$ ratio during dry periods may be further amplified by an additional process: Longer residence times of the percolating water in the host rock result in higher $\mathrm{Mg} / \mathrm{Ca}$ ratios due to the different dissolution characteristics of calcite and dolomite (Fairchild and Treble, 2009).

We interpret the short-term variations in the $\mathrm{Mg} / \mathrm{Ca}$ ratios of the Bunker Cave stalagmites during the Holocene (Fig. 3a) as precipitation variability above the cave. The detrended $\mathrm{Mg} / \mathrm{Ca}$ ratio (Fig. $4 \mathrm{a}$ ) is, therefore, interpreted as a proxy for precipitation amount. Higher $\mathrm{Mg} / \mathrm{Ca}$ ratios in the detrended record are interpreted as dryer periods and vice versa. Based on this interpretation, periods around 0.5, 4.53.7, 5.6 and 7.7-7.3 $\mathrm{kaBP}$ were characterised by relatively dry conditions. This is supported by petrographic analyses. At $5.6 \mathrm{ka}$, a thin coralloid layer was found in Bu4 (Fig. 3b). This kind of calcite fabric is formed from aerosols and can therefore only grow during extremely dry conditions, when there is less drip water available (Hill and Forti, 1997). The period from 7-8 ka in Bu4 consists of columnar and dendritic fabrics indicating dry and unstable conditions (Frisia and Borsato, 2010) and contains a further coralloid layer.

The $\mathrm{Mg} / \mathrm{Ca}$ ratio of Bu1 and its variability is generally lower than that of $\mathrm{Bu} 4$ when comparing coeval time intervals (Fig. 3a). This indicates that Bu1 either experienced a faster drip rate resulting in less PCP or a shorter residence time in the karst aquifer resulting in a lower $\mathrm{Mg}$ concentration due to less intensive dolomite dissolution. This interpretation agrees with the observations reported in Riechelmann et al. (2011) for monthly collected drip water samples from the drip sites above the two speleothems. The recent drip rate of Bu1 is by about two orders of magnitude faster than the drip rate of $\mathrm{Bu} 4$. Furthermore, $\mathrm{Mg}$ isotopes showed that the $\mathrm{Mg}$ contribution to drip waters is variable showing different $\mathrm{Mg}$ proportions derived from the soil and karst, which may explain the $\mathrm{Mg} / \mathrm{Ca}$ offset between stalagmite $\mathrm{Bu} 1$ and $\mathrm{Bu} 4$ (Riechelmann et al., 2012). 


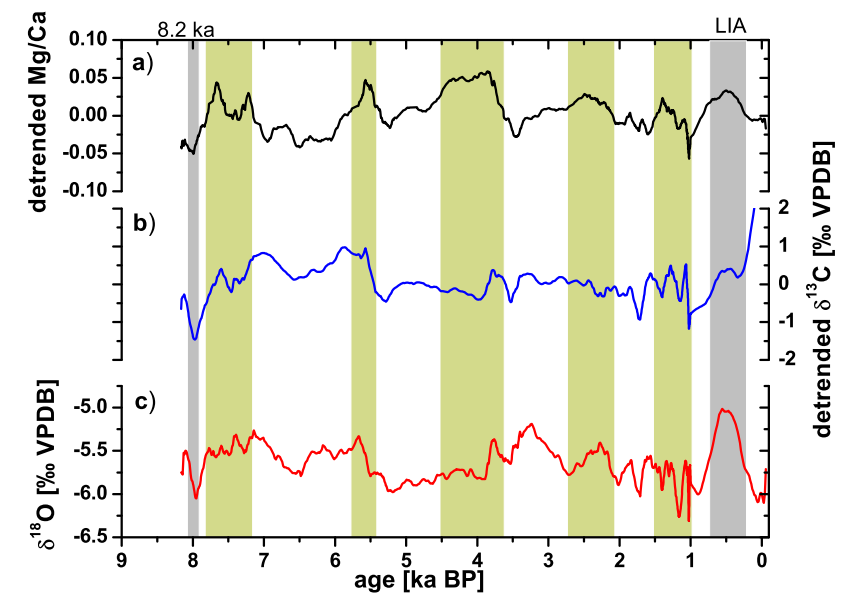

Fig. 4. Comparison of the detrended and smoothed (21-point moving average) $\mathrm{Mg} / \mathrm{Ca}$ ratio (a) and $\delta^{13} \mathrm{C}$ record (b) with the smoothed (21-point moving average) $\delta^{18} \mathrm{O}$ record (c) of $\mathrm{Bu} 4$. The vertical light grey boxes represent the $8.2 \mathrm{ka}$ event and the LIA. The yellow boxes represent periods of below average precipitation as indicated by elevated $\mathrm{Mg} / \mathrm{Ca}$ ratios.

\section{$4.2 \quad \delta^{13} \mathrm{C}$ values}

Monitoring of Bunker Cave drip water (Riechelmann et al., 2011) showed only small variability in the $\delta^{13} \mathrm{C}$ values of annual drip water collected at different drip sites in the cave. Similarly, only small differences in annual cave air $p \mathrm{CO}_{2}$ and $\delta^{13} \mathrm{C}$ were detected. As previously discussed, we reasonably assume that the conditions during the Holocene before the cave was artificially opened were similar. Therefore, we can attribute neither the long-term trend nor the short-term variations in speleothem $\delta^{13} \mathrm{C}$ values (Fig. 3c) to changes in the seasonality of calcite precipitation or cave ventilation as has been demonstrated for other caves (e.g. Spötl et al., 2005; Frisia et al., 2011; Tremaine et al., 2011). The large increase in the $\delta^{13} \mathrm{C}$ values of $\mathrm{Bu} 4$ in the last 250 a (Fig. 3c) is anomalous and may be related to the artificial opening of the cave in the late 19th to early 20th century. The $\delta^{13} \mathrm{C}$ values of the top section of $\mathrm{Bu} 4$ agree well with the $\delta^{13} \mathrm{C}$ values of recent calcite precipitates from this drip site (Riechelmann et al., 2012).

The $\delta{ }^{13} \mathrm{C}$ values of $\mathrm{Bu} 1$ are lower than those of Bu4 during joint growth periods. The mean offset between both records for the last $1.5 \mathrm{ka}$ is ca. $1.3 \%$. This offset may partly reflect differences in the $\delta^{13} \mathrm{C}$ value of the drip water. Modern drip water $\delta^{13} \mathrm{C}$ values differ by approximately $0.13 \%$. In addition, variable kinetic isotope fractionation due to different drip rates may have affected the two speleothems, which would further increase the difference in $\delta^{13} \mathrm{C}$ values (Scholz et al., 2009; Dreybrodt and Scholz, 2011). Today, the drip rate of $\mathrm{Bu} 1$ is about one order of magnitude faster than that of $\mathrm{Bu} 4$, which would result in lower calcite $\delta^{13} \mathrm{C}$ values for $\mathrm{Bu} 1$ in agreement with the measured values.
A similar assessment for the observed differences in stalagmite $\delta^{13} \mathrm{C}$ values is also possible using the measured ${ }^{14} \mathrm{C}$ values (Table 2). Since cave monitoring data suggest that the drip water of both drip sites originates from the same soil water reservoir, the initial soil water $\delta^{13} \mathrm{C}$ and ${ }^{14} \mathrm{C}$ values should be comparable for both drip sites. Thus, the observed variability in the drip water should be related to the process of carbonate dissolution, such as the degree of open versus closed conditions, respectively, as well as potential differences in PCP and kinetic isotope fractionation. Bu1 has a dead carbon fraction (dcf) of approximately $7 \%$, whereas $\mathrm{Bu} 4$ has a dcf of about $12 \%$ (Table 2). According to similar calculations as described in Griffiths et al. (2012), and assuming mean soil air $\delta^{13} \mathrm{C}$ values of about $-23 \%$, host rock $\delta^{13} \mathrm{C}$ values of $+3.5 \%$ (Wurth, 2002) and a mean temperature of $10^{\circ} \mathrm{C}$, the $\delta^{13} \mathrm{C}$ values of the Ca-saturated water feeding $\mathrm{Bu} 1$ should be about 0.5 to $0.6 \%$ lower than that feeding $\mathrm{Bu} 4$. The remaining 0.7 to $0.8 \%$ can be attributed to PCP and kinetic isotope fractionation effects. As mentioned before, $\mathrm{Bu} 4$ is affected by a higher degree of PCP than Bu1, for which this process is negligible (Riechelmann et al., 2011). In chemical equilibrium with about $5000 \mathrm{ppm} \mathrm{CO}_{2}$ as observed in the soil above Bunker Cave, the drip water should have a $\mathrm{HCO}_{3}^{-}$concentration of about $3 \mathrm{mmoll}^{-1}$. The drip water feeding $\mathrm{Bu} 4$ has a mean $\mathrm{HCO}_{3}^{-}$concentration of about $2.3 \mathrm{mmol}^{-1}$. A loss of about $0.7 \mathrm{mmol}^{-1}$ of $\mathrm{HCO}_{3}^{-}$, e.g. during PCP, is sufficient to increase the $\delta^{13} \mathrm{C}$ value by about $0.5 \%$ (Dreybrodt and Scholz, 2011). This would lead to a further enrichment in the $\delta^{13} \mathrm{C}$ value of the drip water arriving at $\mathrm{Bu} 4$ in addition to the carbonate dissolution systematics. Finally, differences in the drip rate lead to a further enrichment in the $\delta^{13} \mathrm{C}$ values (Mühlinghaus et al., 2009; Deininger et al., 2012) of Bu4 and close the gap to the observed $1.3 \%$ offset between both stalagmites.

The increase in the $\delta^{13} \mathrm{C}$ values of about $3 \%$ o during the early Holocene and the subsequent decrease (Fig. 3c) may have been caused by several effects. Higher $\delta^{13} \mathrm{C}$ values may originate from increased kinetic isotope fractionation on the stalagmite surface (Scholz et al., 2009; Mühlinghaus et al., 2009) or even on the stalactite (Frisia et al., 2011) as well as by a larger contribution of host rock-derived $\mathrm{C}$ and/or by lower root respiration and soil microbial activity resulting in more positive soil gas $\delta^{13} \mathrm{C}$ values (Cerling, 1984). Although it is difficult to identify which of these processes dominated the long-term trend in the $\delta^{13} \mathrm{C}$ values of the stalagmite record, we hypothesise that more positive soil air $\delta^{13} \mathrm{C}$ values modulated by vegetation density were the major influence. This assumption is based on the relatively slow adjustment of vegetation compared to the faster reaction time of carbonate dissolution or stable isotope fractionation to climatically induced changes. Hence, changes in root respiration and microbial activity due to changes in vegetation density seem to be responsible for increasing soil air $\delta^{13} \mathrm{C}$ values probably due to lower soil respiration rates between 9 and 
$7 \mathrm{ka} \mathrm{BP}$. This implies that the vegetation cover above the cave became thinner during this interval, which may be related to the relatively dry conditions between 7.7 and $7.3 \mathrm{ka} \mathrm{BP}$ inferred from the $\mathrm{Mg} / \mathrm{Ca}$ ratio (Fig. 4a). After $6 \mathrm{ka}$, the stalagmite $\delta^{13} \mathrm{C}$ signal decreases implying the development of a denser vegetation cover or a thickening of the soil above the cave with concomitant higher soil bioproductivity.

Superimposed on this first-order trend in $\delta^{13} \mathrm{C}$, a higher frequency pattern is visible. This pattern resembles the second-order signal in $\mathrm{Mg} / \mathrm{Ca}$ and is attributed to cave internal processes such as kinetic isotope fractionation. The degree of kinetic $\mathrm{C}$ isotope fractionation is mainly influenced by variations in drip rate (Dreybrodt, 2008; Mühlinghaus et al., 2009; Scholz et al., 2009; Deininger et al., 2012), which in turn reflects changes in karst hydrology and precipitation above the cave. Therefore, high $\delta^{13} \mathrm{C}$ values are assigned to periods of low drip rates and vice versa. Apart from periodically appearing differences, the overall similarity of the detrended and smoothed time series of $\mathrm{Mg} / \mathrm{Ca}$ and $\delta^{13} \mathrm{C}$ for Bu4 (Fig. $4 \mathrm{a}$ and $\mathrm{b}$ ) implies that slow drip rates correspond to periods of less precipitation.

\section{$4.3 \quad \delta^{18} \mathrm{O}$ values}

Applying conventional evapotranspiration equations, Wackerbarth et al. (2010) estimated that about $40-50 \%$ of the annual precipitation is lost due to evapotranspiration processes. Thus, the contribution of summer precipitation to recharge of the karst aquifer is very low in the cave region. Furthermore, Münsterer et al. (2012) demonstrated, based on analysis of ${ }^{36} \mathrm{Cl}$, that the annual amount of evapotranspiration is even higher and may reach values between 68 and $88 \%$. Thus, winter precipitation is the major proportion of the cave drip water and dominates its $\delta^{18} \mathrm{O}$ value.

The relationship between surface air temperature and $\delta^{18} \mathrm{O}$ of precipitation is positive $\left(\approx 0.1-0.3 \% 0^{\circ} \mathrm{C}^{-1}\right)$ and differs depending on the geographical position of the cave (Fricke and O'Neil, 1999). The temperature dependence of oxygen isotope fractionation during calcite precipitation counteracts this effect $\left(-0.24 \% 0^{\circ} \mathrm{C}^{-1}\right)$. Therefore, the relationship between $\delta^{18} \mathrm{O}$ of calcite and surface temperature depends on the individual cave. Wackerbarth et al. (2010) demonstrated that the relationship is negative for Bunker Cave. The reason is a positive relationship between winter temperature and winter precipitation. Although warmer temperatures during winter lead to higher $\delta^{18} \mathrm{O}$ values in precipitation, they increase the amount of winter precipitation and its contribution to the drip water. Since winter precipitation has significantly lower $\delta^{18} \mathrm{O}$ values than precipitation from the other seasons, this leads in total to lower $\delta^{18} \mathrm{O}$ values of cave drip water and calcite. This explains the negative relationship between $\delta^{18} \mathrm{O}$ values in calcite and temperature as predicted by the temperature$\delta^{18} \mathrm{O}$ relationship during calcite precipitation. In addition, in case of kinetic isotope fractionation, higher drip rates (probably due to increased precipitation) would also result in lower $\delta^{18} \mathrm{O}$ values (Mühlinghaus et al., 2009; Scholz et al., 2009; Dreybrodt and Scholz, 2011; Deininger et al., 2012). Therefore, we interpret the observed variations in speleothem $\delta^{18} \mathrm{O}$ as changes in both surface winter temperature and amount of winter precipitation. More positive $\delta^{18} \mathrm{O}$ values reflect cold and dry winters, whereas more negative $\delta^{18} \mathrm{O}$ values represent warmer and more humid winters.

In most periods, the smoothed $\delta^{18} \mathrm{O}$ record of $\mathrm{Bu} 4$ (21point moving average) for the last $8 \mathrm{ka}$ (Fig. 4c) shows large similarities with the detrended and smoothed $\mathrm{Mg} / \mathrm{Ca}$ record (Fig. 4a). During relatively dry conditions (high $\mathrm{Mg} / \mathrm{Ca}$ ratio), the $\delta^{18} \mathrm{O}$ values show more positive values than during relatively humid conditions (low $\mathrm{Mg} / \mathrm{Ca}$ ratio). This pattern is particularly pronounced between 7.8 and $7.3 \mathrm{ka}, 6$ and $5.5 \mathrm{ka}, 2.8$ and $2.2 \mathrm{ka}$ and during the LIA. In contrast, this relationship of high $\mathrm{Mg} / \mathrm{Ca}$ and high $\delta^{18} \mathrm{O}$ does not hold for the period from 4.5 to $3.5 \mathrm{ka}$. As described above, changes in carbonate dissolution processes and PCP may be responsible for the observed variability in $\mathrm{Mg} / \mathrm{Ca}$. Variable PCP may also affect the $\delta^{18} \mathrm{O}$ signal. However, for the Bunker Cave stalagmites, PCP seems not to be of major importance for the $\delta^{18} \mathrm{O}$ values. This is confirmed by the differences in the $\mathrm{Mg} / \mathrm{Ca}$ ratios of Bu1 and Bu4 (Fig. 3a). Bu1 only shows small variations in $\mathrm{Mg} / \mathrm{Ca}$ indicating negligible $\mathrm{PCP}$, but the $\delta^{18} \mathrm{O}$ values are very similar to those of $\mathrm{Bu} 4$, which shows relatively large variations in $\mathrm{Mg} / \mathrm{Ca}$ suggesting a strong PCP. Furthermore, peaks in the $\mathrm{Mg} / \mathrm{Ca}$ ratio of $\mathrm{Bu} 4$ are in most cases not coeval with peaks in $\delta^{18} \mathrm{O}$ (Fig. 4), which provides additional evidence that PCP did not strongly influence the speleothem $\delta^{18} \mathrm{O}$ values in Bunker Cave.

Data and modelling studies (Baldini et al., 2008; Langebroek et al., 2011) showed that $\delta^{18} \mathrm{O}$ values in precipitation over central Western Europe are influenced by a North Atlantic Oscillation (NAO)-like pattern. As argued in Langebroek et al. (2011), the correlation pattern between the $\delta^{18} \mathrm{O}$ value of precipitation and atmospheric circulation over $\mathrm{Eu}-$ rope is a result of the combined effect of temperature and precipitation. Heat and moisture are mainly transported to the European continent from the North Atlantic by the westerlies. Therefore, climate-related signals from the North Atlantic (e.g. the hematite-stained grains (HSG) record; Bond et al., 2001) and the Bunker Cave $\delta^{18} \mathrm{O}$ record are expected to show similar variations (Fig. 5). Cold periods, as indicated by increased percentages of HSG, indeed coincide in most cases with colder phases in western Germany (high $\delta^{18} \mathrm{O}$ values in speleothem calcite). Nevertheless, for certain periods, changes in storm tracks, which could be caused by the reorganisation of atmospheric circulation towards the end of the deglaciation, may also have contributed to the variability of the $\delta^{18} \mathrm{O}$ values in the speleothem calcite. The increase in the $\delta^{18} \mathrm{O}$ values during the early Holocene (between 10 and $8.5 \mathrm{ka}$ ) may rather be ascribed to such changes than to a decrease in temperature. For instance, the source region could have been shifted from southern locations with a lower $\delta^{18} \mathrm{O}$ value of the surface water to locations further north 


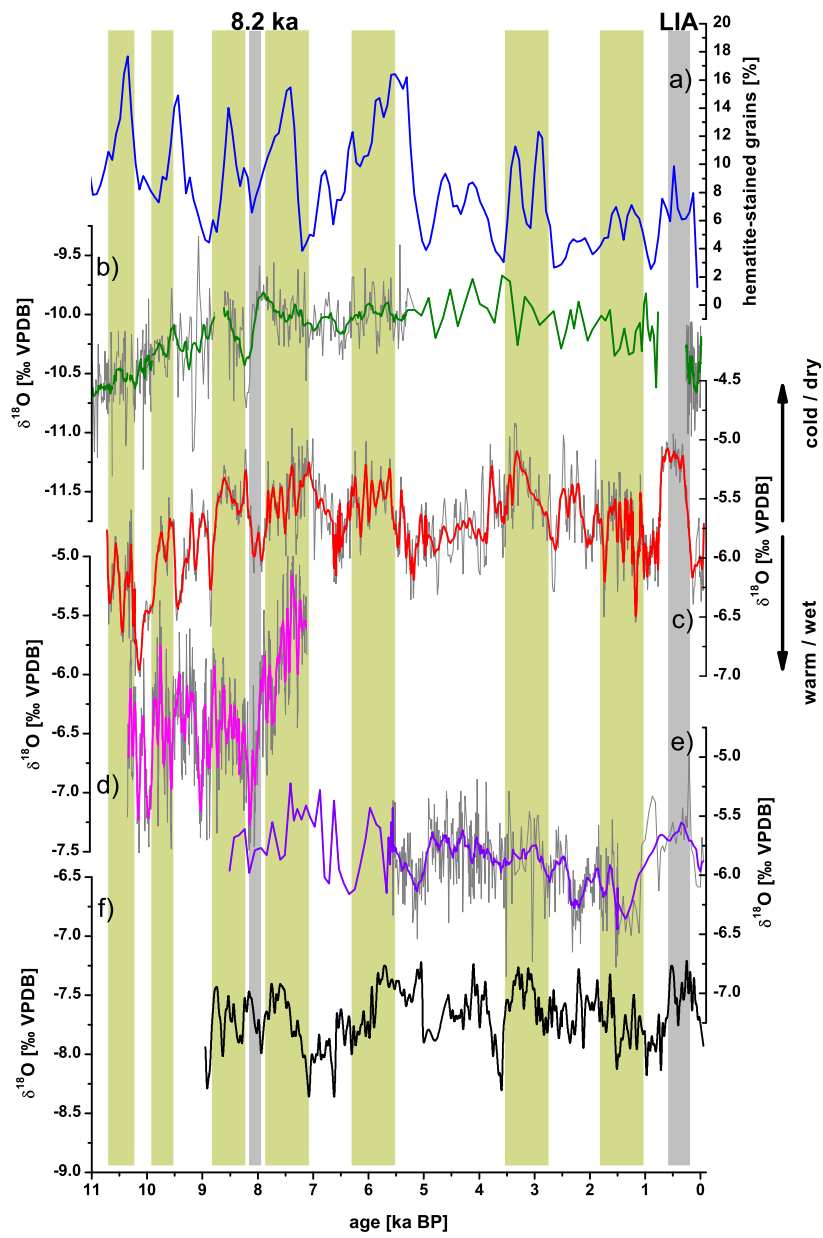

Fig. 5. (c) Composite $\delta^{18} \mathrm{O}$ record from Bunker Cave in comparison to (a) hematite-stained grains from the North Atlantic (Bond et al., 2001), (b) Lake Ammersee (about $550 \mathrm{~km}$ south-east of Bunker Cave) a proxy of $\delta^{18} \mathrm{O}$ of meteoric precipitation (von Grafenstein et al., 1998, 1999), (d) $\delta^{18} \mathrm{O}$ record from Katerloch (Boch et al., 2009), (e) $\delta^{18} \mathrm{O}$ record from stalagmite AH1 (Niggemann, 2000; Niggemann et al., 2003) from the Atta Cave (about $50 \mathrm{~km}$ south of Bunker Cave) and (f) the $\delta^{18} \mathrm{O}$ record from the Austrian Alps (COMNISPA, Vollweiler et al., 2006). Thin grey lines represent the original data, which were smoothed with an 11-point moving average (coloured thick lines). The Ammersee data between 5.35 and $0.8 \mathrm{ka}$ and the $\mathrm{AH} 1$ data between 8.5 and $6 \mathrm{kaBP}$ are not smoothed due to their low temporal resolution. The AH1 data are shown on a new age-scale calculated with StalAge (Scholz and Hoffmann, 2011).

with higher $\delta^{18} \mathrm{O}$ values in the surface water (Duplessy et al., 1992).

Ostracod $\delta^{18} \mathrm{O}$ values from Lake Ammersee (von Grafenstein et al., 1998, 1999) reflect the $\delta^{18} \mathrm{O}$ value of precipitation (Fig. 5b) over the northern rim of the Alps and are here used to constrain the $\delta^{18} \mathrm{O}$ value of soil water above Bunker Cave. The signal-to-noise ratio of the Ammersee data is comparable to that of the composite Bunker Cave $\delta^{18} \mathrm{O}$ record (Fig. 5c). Throughout the Holocene, the composite $\delta^{18} \mathrm{O}$ record of the four Bunker Cave stalagmites shows values ranging from -7 to $-5 \%$ and broadly follows the precipitation $\delta^{18} \mathrm{O}$ signal reconstructed from Lake Ammersee. However, the Bunker Cave $\delta^{18} \mathrm{O}$ data highlight longer periods of high or low $\delta^{18} \mathrm{O}$ values whose amplitude is also larger than that of the Ammersee record, suggesting that processes in soil and cave may modify the $\delta^{18} \mathrm{O}$ value of the rainfall preserved in the stalagmites. In particular, variations in the (degree of) kinetic isotope fractionation may have a strong influence.

When comparing the Bunker Cave $\delta^{18} \mathrm{O}$ record with the $\delta^{18} \mathrm{O}$ records from Atta Cave (Niggemann, 2000; Niggemann et al., 2003), Katerloch (Boch et al., 2009) and Spannagel Cave (Vollweiler et al., 2006), a similar structure is observed in all records. This indicates that the signal encoded in the Bunker Cave stalagmites represents supra-regional climate variability. A comparison of the composite Bunker Cave record and the other European stalagmite archives (Fig. 5) with the HSG record from the North Atlantic (Bond et al., 2001) suggests that the signal from the central European continent may even be representative for the North Atlantic region and large parts of Europe.

\subsubsection{Little Ice Age vs. 8.2 ka event}

Two prominent features in the composite Bunker Cave $\delta^{18} \mathrm{O}$ record (Fig. 5c) are the $8.2 \mathrm{ka}$ event and the LIA, which occurred between 0.7 and $0.2 \mathrm{kaBP}$. The LIA is characterized by high $\mathrm{Mg} / \mathrm{Ca}$ ratios as well as prominent maxima in $\delta^{13} \mathrm{C}$ and $\delta^{18} \mathrm{O}$ in the Bunker record. The $\delta^{18} \mathrm{O}$ values are the highest of the entire record. According to our interpretation, this shows that, during the LIA, central Europe experienced anomalously cold and dry winter conditions in agreement with the cold conditions observed in the North Atlantic (Bond et al., 2001) and the idea of a pronounced negative anomaly of the NAO during this period (Trouet et al., 2009).

Another prominent Holocene cold event was the $8.2 \mathrm{ka}$ event, which shows the opposite behaviour in the Bunker Cave $\delta^{18} \mathrm{O}$ signal. This indicates that the origin of the cold events differs. The abrupt $8.2 \mathrm{ka}$ event brought generally cold and dry conditions to the Northern Hemisphere, in particular during winter (Alley et al., 1997; Alley and Ágústsdóttir, 2005). This event was triggered by large amounts of melt water originating from the North American continent that freshened the North Atlantic and influenced the North Atlantic circulation by a curtailment of North Atlantic Deep Water (NADW) formation (Alley et al., 1997; Barber et al., 1999; Rohling and Pälike, 2005). In central-northern Europe, this event led to more negative $\delta^{18} \mathrm{O}$ values in precipitation (von Grafenstein et al., 1999; LeGrande and Schmidt, 2008). This depletion in rainfall $\delta^{18} \mathrm{O}$ is also recorded in the Bunker Cave $\delta^{18} \mathrm{O}$ record (Fig. 5). However, the amplitude of the $8.2 \mathrm{ka}$ event in the stalagmite record $(\approx 0.4 \%)$ is lower than in the Ammersee precipitation record $(\approx 0.7 \%$ ), using for both 
numbers $\mathrm{a} \approx \pm 600 \mathrm{a}$ window around the main event. This dampening most likely reflects the temperature decrease, which is responsible for a stronger oxygen isotope fractionation and consequently for more positive $\delta^{18} \mathrm{O}$ values during colder periods. Following Mühlinghaus et al. (2009), the difference in the observed $\delta^{18} \mathrm{O}$ amplitudes can be obtained by a $1.2{ }^{\circ} \mathrm{C}$ cooling during the $8.2 \mathrm{ka}$ event assuming present-day drip rates for the $\Delta \delta^{18} \mathrm{O} / \Delta \mathrm{T}$ slope $\left(\approx 0.25 \% \circ \mathrm{K}^{-1}\right)$. This estimate is slightly smaller than the temperature drop deduced from the Ammersee data (1.7; von Grafenstein et al., 1998). Throughout the North Atlantic and central-northern European region, the sharp $8.2 \mathrm{ka}$ event occurs within a broader anomaly (Rohling and Pälike, 2005). However, this wider, more subtle depletion is not observed in the Bunker Cave stalagmites. Furthermore, the $\mathrm{Mg} / \mathrm{Ca}$ ratios of the Bunker Cave record are relatively low during the $8.2 \mathrm{ka}$ event (Fig. 4a) suggesting average or even slightly more humid conditions. Thus, climate conditions were probably not exceptionally dry in central Europe during the $8.2 \mathrm{ka}$ event.

\section{Conclusions}

We present multi-proxy data of four partly overlapping Holocene stalagmites collected within a distance of $12 \mathrm{~m}$ in Bunker Cave. After the pioneering multi-proxy record from three stalagmites from Marcelo Arévalo-cave in Chile (Schimpf et al., 2011), this is, to the best of our knowledge, one of the first available multi-proxy, multi-record stalagmite studies. The individual proxy time series agree well between the four stalagmites, which suggests that the observed signals are climate related. We use the $\delta^{18} \mathrm{O}$ values to improve the age-depth model with a recently published age-depth modelling software (iscam, Fohlmeister, 2012). In addition, we show for the first time that differences in the $\delta^{13} \mathrm{C}$ values between two stalagmites (Bu1 and $\mathrm{Bu} 4)$ were partly caused by carbonate dissolution dynamics $(\approx 40 \%)$. The remaining $\approx 60 \%$ of the differences are a result of PCP and the difference in the drip rate. This range is in agreement with isotope fractionation modelling studies.

The measured $\mathrm{Mg} / \mathrm{Ca}$ ratio, $\delta^{13} \mathrm{C}$ and $\delta^{18} \mathrm{O}$ values allow a reconstruction of past winter climate variability in central Europe. High $\mathrm{Mg} / \mathrm{Ca}$ values in the detrended record highlight dry periods within the Holocene. Accordingly, high $\delta^{13} \mathrm{C}$ values of the detrended record are ascribed to low drip rates due to dry conditions above the cave. More positive $\delta^{18} \mathrm{O}$ values during the last $10.8 \mathrm{ka}$ reflect colder and dryer winters. An exception in this context is the $8.2 \mathrm{ka}$ cold event, which shows a prominent negative $\delta^{18} \mathrm{O}$ excursion. A wider, more subtle cooling around the $8.2 \mathrm{ka}$ event is not observed. The lower $\delta^{18} \mathrm{O}$ values during the cold event are ascribed to a negative anomaly in the $\delta^{18} \mathrm{O}$ values of precipitation over central Europe triggered by changes in the North Atlantic Ocean circulation due to increased freshwater input. For the $8.2 \mathrm{ka}$ event, we estimate the temperature anomaly to be about $-1.2{ }^{\circ} \mathrm{C}$ at our location. The stalagmite $\mathrm{Mg} / \mathrm{Ca}$ ratios show no anomaly during this period indicating that the amount of precipitation did not change considerably at our site. In addition, the $\delta^{18} \mathrm{O}$ values during the two main cold events (i.e. $8.2 \mathrm{ka}$ event and the LIA) show an opposite behaviour clearly indicating that the underlying climatic processes are completely different. Finally, we show that the $\delta^{18} \mathrm{O}$ values from the Bunker Cave stalagmites agree well with other central European climate archives as well as with records from the North Atlantic. The similarity between the North Atlantic and central Europe records can be ascribed to the prevailing westerlies, which transported the climatic signal from the Atlantic to the continent. Cold and dry periods are observed between 8 and $7 \mathrm{ka}, 6.5$ and $5.5 \mathrm{ka}, 4$ and $3 \mathrm{ka}$ as well as between 0.7 and $0.2 \mathrm{ka}$.

Acknowledgements. This work was funded by DFG research grant FG 668 (DAPHNE). We would like two thank two anonymous reviewers and Associate Editor, Silvia Frisia, for their thorough reviews and helpful comments, which helped to improve the manuscript.

Edited by: S. Frisia

\section{References}

Alley, R. B. and Ágústsdóttir, A. M.: The 8 k event: Cause and consequences of a major Holocene abrupt climate change, Quaternary Sci. Rev., 24, 1123-1149, 2005.

Alley, R. B., Mayewski, P. A., Sowers, T., Stuiver, M., Taylor, K. C., and Clark, P. U.: Holocene climatic instability: A prominent, widespread event $8200 \mathrm{yr}$ ago, Geology, 25, 483-486, 1997.

Baldini, J. U. L., McDermott, F., Hoffmann, D. L., Richards, D. A., and Clipson, N.: Very high-frequency and seasonal cave atmosphere $p \mathrm{CO}_{2}$ Variability: Implications for stalagmite growth and oxygen isotope-based paleoclimate records, Earth Planet. Sc. Lett., 272, 118-129, 2008.

Barber, D. C., Dyke, A., Hillaire-Marcel, C., Jennings, A. E., Andrews, J. T., Kerwin, M. W., Bilodeau, G., McNeely, R., Southon, J., Morehead, M. D., and Gagnon, J.-M.: Forcing of the cold event of 8,200 years ago by catastrophic drainage of Laurentide lakes, Nature, 400, 344-348, 1999.

Boch, R., Spötl, C., and Kramers, J.: High-resolution isotope records of early Holocene rapid climate change from two coeval stalagmites of Katerloch Cave, Austria, Quaternary Sci. Rev., 28, 2527-2538, 2009.

Bond, G., Kromer, B., Beer, J., Muscheler, R., Evans, M., Showers, W., Hoffmann, S., Lotti-Bond, R., Hajdas, I., and Bonani, G.: Persistent solar influence on North Atlantic climate during the Holocene, Science, 294, 2130-2136, 2001.

Büntgen, U., Trouet, V., Frank, D., Leuschner, H. H., Friedrichs, D., Luterbacher, J., and Esper, J.: Tree-ring indicators of German summer drought over the last millennium, Quaternary Sci. Rev., 29, 1005-1016, 2010.

Cerling, T. E.: The stable isotopic composition of modern soil carbonate and its relationships to climate, Earth Planet. Sc. Lett., 71, 229-240, 1984. 
Cheng, H., Edwards, R. L., Hoff, J., Gallup, C. D., Richards, D. A., and Asmerom, Y.: The half-lives of uranium-234 and thorium230, Chem. Geol., 169, 17-33, 2000.

Cruz Jr., F. W., Burns, S. J., Jercinovic, M., Karmann, I., Sharp, W. D., and Vuille, M.: Evidence of rainfall variations in southern Brazil from trace element ratios $(\mathrm{Mg} / \mathrm{Ca}$ and $\mathrm{Sr} / \mathrm{Ca})$ in a rate Pleistocene stalagmite, Geochim. Cosmochim. Ac., 71, 22502263, 2007.

Davis, B. A. S., Brewer, S., Stevenson, A. C., and Guiot, J.: The temperature of Europe during the Holocene reconstructed from pollen data, Quaternary Sci. Rev., 22, 1701-1716, 2003.

Deininger, M., Fohlmeister, J., Scholz, D., and Mangini, A.: The influence of evaporation effects on the carbon and oxygen isotope composition of speleothems - a model approach, Geochim. Cosmochim. Ac., 96, 57-79, doi:10.1016/j.gca.2012.08.013, 2012.

Dreybrodt, W.: Evolution of isotopic composition of carbon and oxygen in a calcite precipitating $\mathrm{H}_{2} \mathrm{O}-\mathrm{CO}_{2}-\mathrm{CaCO}_{3}$ solution and the related isotopic composition of calcite in stalagmites, Geochim. Cosmochim. Ac., 72, 4712-4724, 2008.

Dreybrodt, W. and Scholz, D.: Climatic dependence of stable carbon and oxygen isotope signals recorded in speleothems: From soil water to speleothem calcite, Geochim. Cosmochim. Ac., 75, 734-752, 2011.

Duplessy, J., Labeyrie, L., Arnold, M., Paterne, M., Duprat, J., and van Weering, T.: Changes in surface salinity of the North Atlantic Ocean during the last deglaciation, Nature, 358, 485-488, 1992.

Fairchild, I. J. and Treble, P. C.: Trace elements in speleothems as recorders of environmental change, Quaternary Sci. Rev., 28, 449-468, 2009.

Fohlmeister, J.: A statistical approach to construct composite climate records of dated archives, Quat. Geochronol., online first: doi:10.1016/j.quageo.2012.06.007, 2012.

Fohlmeister, J., Kromer, B., and Mangini, A.: The influence of soil organic matter age spectrum on the reconstruction of atmospheric ${ }^{14} \mathrm{C}$ levels via stalagmites, Radiocarbon, 53, 99-115, 2011.

Frank, N., Braum, M., Hambach, U., Mangini, A., and Wagner, G.: Warm period growth of travertine during the last interglaciation in southern Germany, Quaternary Res., 54, 38-48, 2000.

Fricke, H. C. and O'Neil, J. R.: The correlation between ${ }^{18} \mathrm{O} /{ }_{16} \mathrm{O}$ ratios of meteoric water and surface temperature: its use in investigating terrestrial climate change over geologic time, Earth Planet. Sc. Lett., 170, 181-196, 1999.

Friedrich, M., Kromer, B., Spurk, M., Hofmann, J., and Kaiser, K. F.: Paleo-environment and radiocarbon calibration as derived from lateglacial/early Holocene tree-ring chronologies, Quaternary Int., 61, 27-39, 1999.

Frisia, S. and Borsato, A.: Karst, Developments in Sedimentology, 61, 269-318, 2010.

Frisia, S., Borsato, A., Preto, N., and McDermott, F.: Late Holocene annual growth in three alpine stalagmites records the influence of solar activity and the North Atlantic oscillation on winter climate, Earth Planet. Sc. Lett., 216, 411-424, 2003.

Frisia, S., Fairchild, I. J., Fohlmeister, J., Miorandi, R., Spötl, C., and Borsato, A.: Carbon mass-balance modelling and carbon isotope exchange processes in dynamic caves, Geochim. Cosmochim. Ac., 75, 380-400, 2011.

Genty, D. and Massault, M.: Carbon transfer dynamics from bomb- ${ }^{14} \mathrm{C}$ and $\delta^{13} \mathrm{C}$ time series of a laminated stalagmite from
SW France - Modeling and comparison with other stalagmite records, Geochim. Cosmochim. Ac., 63, 1537-1548, 1999.

Gerdes, A. and Zeh, A.: Combined U-Pb and Hf isotope LA(MC-)ICP-MS analyses of detrital zircons: Comparison with SHRIMP and new constraints for the provenance and age of an armorican metasediment in Central Germany, Earth Planet. Sc. Lett., 249, 41-67, 2006.

Griffiths, M. L., Fohlmeister, J., Drysdale, R. N., Hua, Q., Johnson, K. R., Hellstrom, J. C., Gagan, M. K., and Zhao, J.X.: Hydrological control on the dead-carbon content of a Holocene tropical speleothem, Quat. Geochronol., online first: doi:10.1016/j.quageo.2012.04.001, 2012.

Guiot, J., Harrison, S. P., and Prentice, I. C.: Reconstruction of Holocene precipitation patterns in Europe using pollen and lakelevel data, Quaternary Res., 40, 139-149, 1993.

Hill, C. and Forti, P.: Cave minerals of the world, Vol. 2, National speleological society, Huntsville, AL, 1997.

Hoffmann, D. L., Prytulak, J., Richards, D. A., Elliott, T., Coath, C. D., Smart, P. L., and Scholz, D.: Procedures for accurate U and Th isotope measurements by high precision MC-ICPMS, Int. J. Mass Spectrom., 264, 97-109, 2007.

Holzhauser, H., Magny, M., and Zumbühl, H. J.: Glacier and lakelevel variations in West-Central Europe over the last 3500 years, Holocene, 15, 789-801, 2005.

Holzkämper, S., Spötl, C., and Mangini, A.: High-precision constraints on timing of alpine warm periods during the middle to late Pleistocene using speleothem growth periods, Earth Planet. Sc. Lett., 236, 751-764, 2005.

Hua, Q. and Barbetti, M.: Review of tropospheric bomb ${ }^{14} \mathrm{C}$ data for carbon cycle Modeling and age calibration purposes, Radiocarbon, 46, 1273-1298, 2004.

Immenhauser, A., Buhl, D., Richter, D. K., Niedermayr, A., Riechelmann, D. F. C., Dietzel, M., and Schulte, U.: Magnesiumisotope fractionation during low- $\mathrm{Mg}$ calcite precipitation in a limestone cave - field study and experiments, Geochim. Cosmochim. Ac., 74, 4346-4364, 2010.

Ivy-Ochs, S., Kerschner, H., Maisch, M., Christl, M., Kubik, P. W., and Schlüchter, C.: Latest Pleistocene and Holocene glacier variations in the European Alps, Quaternary Sci. Rev., 28, 21372149, 2009.

Joerin, U. E., Stocker, T. F., and Schlüchter, C.: Multicentury glacier fluctuations in the Swiss Alps during the Holocene, Holocene, 16, 697-704, 2006.

Kim, S.-T. and O'Neil, J. R.: Equilibrium and nonequilibrium oxygen isotope effects in synthetic carbonates, Geochim. Cosmochim. Ac., 61, 3461-3475, 1997.

Kluge, T., Riechelmann, D. F. C., Wieser, M., Spötl, C., Sültenfü̈, J., Schröder-Ritzrau, A., Niggemann, S., and Aeschbach-Hertig, W.: Dating cave drip water by tritium, J. Hydrol., 349, 396-406, 2010.

Langebroek, P. M., Werner, M., and Lohmann, G.: Climate information imprinted in oxygen-isotopic composition of precipitation in Europe, Earth Planet. Sc. Lett., 311, 144-154, 2011.

LeGrande, A. N. and Schmidt, G. A.: Ensemble, water isotope-enabled, coupled general circulation modeling insights into the $8.2 \mathrm{ka}$ event, Paleoceanography, 23, PA3207, doi:10.1029/2008PA001610, 2008.

Levin, I. and Kromer, B.: The tropospheric ${ }^{14} \mathrm{CO}_{2}$ level in midlatitudes of the Northern Hemisphere (1959-2003), Radiocar- 
bon, 46, 1261-1272, 2004.

Magny, M.: Holocene climate variability as reflected by midEuropean lake-level fluctuations and its probable impact on prehistoric human settlements, Quaternary Int., 113, 65-79, 2004.

Mangini, A., Spötl, C., and Verdes, P.: Reconstruction of temperature in the Central Alps during the past $2000 \mathrm{yr}$ from a $\delta^{18} \mathrm{O}$ stalagmite record, Earth Planet. Sc. Lett., 235, 741-751, 2005.

Mattey, D., Lowry, D., Duffet, J., Fisher, R., Hodge, E., and Frisia, S.: A 53 year seasonally resolved oxygen and carbon isotope record from a modern Gibraltar speleothem: Reconstructed drip water and relationship to local precipitation, Earth Planet. Sc. Lett., 269, 80-95, 2008.

McDermott, F., Frisia, S., Huang, Y., Longinelli, A., Spiro, B., Heaton, T. H. E., Hawkesworth, C. J., Borsato, A., Keppens, E., Fairchild, I. J., van der Borg, K., Verheyden, S., and Selmo, E. M.: Holocene climate variability in Europe: Evidence from $\delta^{18} \mathrm{O}$, textural and extension-rate variations in three speleothems, Quaternary Sci. Rev., 18, 1021-1038, 1999.

Mühlinghaus, C., Scholz, D., and Mangini, A.: Modelling fractionation of stable isotopes in stalagmites, Geochim. Cosmochim. Ac., 71, 2780-2790, 2009.

Münsterer, C., Fohlmeister, J., Wackerbarth, A., Christl, M., Schröder-Ritzrau, A., Alfimov, V., Ivy-Ochs, S., and Mangini, A.: Cosmogenic ${ }^{36} \mathrm{Cl}$ in karst waters from Bunker Cave, North Western Germany - A tool to derive local evapotranspiration?, Geochim. Cosmochim. Ac., doi:10.1016/j.gca.2012.03.008, 2012

Neuser, R. D., Bruhn, F., Götze, J., Habermann, D., and Richter, D. K.: Kathodolumineszenz: Methodik und Anwendung, Zbl. Geo. Pal., 1/2, 287-306, 1995.

Niggemann, S.: Klimabezogene Untersuchung an spät- und postglazialen Stalagmiten aus Massenkalkhöhlen des Sauerlandes, in: Beiträge zur Speläologie I, edited by: Richter, D. K. and Wurth, G., 5-129, Bochumer geologische und geotechnische Arbeiten, Ruhr-University Bochum, 2000.

Niggemann, S., Mangini, A., Mudelsee, M., Richter, D. K., and Wurth, G.: Sub-Milankovitch climatic cycles in Holocene stalagmites from Sauerland, Germany, Earth Planet. Sc. Lett., 216, 539-547, 2003

North Greenland Ice Core Project members: High-Resolution record of northern Hemisphere climate extending into the last interglacial period, Nature, 431, 147-151, 2004

Pearce, N. J. G., Perkins, W. T., Westgate, J. A., Gorton, M. P., Jackson, S. E., Neal, C. N., and Chenery, S.: A compilation of new and published major and trace element data for NIST SRM 610 and NIST SRM 612 glass reference material, Geostandard. Newslett., 21, 115-144, 1996.

Richter, D., Gotte, T., Niggemann, S., and Wurth, G.: REE3+ and $\mathrm{Mn} 2+$ activated cathodoluminescence in lateglacial and Holocene stalagmites of central Europe: Evidence for climatic processes?, Holocene, 14, 759-768, 2004.

Riechelmann, D. F. C., Schröder-Ritzrau, A., Scholz, D., Fohlmeister, J., Spötl, C., Richter, D. K., and Mangini, A.: Monitoring of the Bunker Cave (NW Germany): Assessing the complexity of cave environmental parameters, J. Hydrol., 409, 682-695, 2011.

Riechelmann, D. F. C., Deininger, M., Scholz, D., Riechelmann, S., Schröder-Ritzrau, A., Spötl, C., Richter, D. K., Immenhauser, A., and Mangini, A.: Disequilibrium carbon and oxygen isotope fractionation in recent cave calcite: Comparison of cave precipi- tates and numerical model $\delta^{13} \mathrm{C}$ and $\delta^{18} \mathrm{O}$ data, Geochim. Cosmochim. Ac., in review, 2012.

Riechelmann, S., Buhl, D., Schröder-Ritzrau, A., Spötl, C., Riechelmann, D. F. C., Richter, D. K., Kluge, T., Marx, T., and Immenhauser, A.: Hydrogeochemistry and fractionation pathways of $\mathrm{Mg}$ isotopes in a continental weathering system: Lessons from field experiments, Chem. Geol., 300, 109-122, 2012.

Rohling, E. J. and Pälike, H.: Centennial-scale climate cooling with a sudden cold event around 8,200 years ago, Nature, 434, 975979, 2005.

Schimpf, D., Kilian, R., Kronz, A., Simon, K., Spötl, C., Worner, G., Deininger, M., and Mangini, A.: The significance of chemical, isotopic, and detrital components in three coeval stalagmites from the superhumid southernmost Andes $\left(53^{\circ} \mathrm{S}\right)$ as highresolution palaeo-climate proxies, Quaternary Sci. Rev., 30, 443 459, 2011.

Scholz, D. and Hoffmann, D.: StalAge - an algorithm designed for construction of speleothem age models, Quat. Geochronol., 6, 369-382, 2011.

Scholz, D., Mühlinghaus, C., and Mangini, A.: Modelling $\delta^{13} \mathrm{C}$ and $\delta^{18} \mathrm{O}$ in the solution layer on stalagmite surfaces, Geochim. Cosmochim Ac., 73, 2592-2602, 2009.

Spötl, C. and Mattey, D.: Stable isotope microsampling of speleothems for palaeoenvironmental studies: A comparison of microdrill, micromill and laser ablation techniques, Chem. Geol., 235, 48-58, 2006

Spötl, C., Faichild, I. J., and Tooth, A. F.: Cave air control on dripwater geochemistry, Obir Cave (Austria): Implications for speleothem deposition in dynamically ventilated caves, Geochim. Cosmochim. Ac., 69, 2451-2468, 2005.

Spurk, M., Leuschner, H. H., Baillie, M. G. L., Briffa, K. R., and Friedrich, M.: Depositional frequency of German subfossil oaks: Climatically and non-climatically induced fluctuations in the Holocene, Holocene, 12, 707-715, 2002.

Synal, H.-A., Stocker, M., and Suter, M.: MICADAS: A new compact radiocarbon AMS system, Nucl. Instrum. Meth. B, 259, 713,2007

Tooth, A. F. and Fairchild, I. J.: Soil and karst aquifer hydrological controls on the geochemical evolution of speleothem-forming drip waters, Crag Cave, southwest Ireland, J. Hydrol., 273, 51$68,2003$.

Tremaine, D. M., Froelich, P. N., and Wang, Y.: Speleothem calcite farmed in situ: Modern calibration of $\delta^{18} \mathrm{O}$ and $\delta^{13} \mathrm{C}$ paleoclimate proxies in a continuously-monitored natural cave system, Geochim. Cosmochim. Ac., 75, 4929-4950, 2011.

Trouet, V., Esper, J., Graham, N. E., Baker, A., Scourse, J. D., and Frank, D. C.: Persistent positive North Atlantic Oscillation mode dominated the medieval climate anomaly, Science, 324, 78-80, 2009.

Vollweiler, N., Scholz, D., Mühlinghaus, C., Mangini, A., and Spötl, C.: A precisely dated climate record for the last $9 \mathrm{kyr}$ from three high alpine stalagmites, Spannagel Cave, Austria, Geophys. Res. Lett., 33, L20703, doi:10.1029/2006GL027662, 2006.

von Grafenstein, U., Erlenkeuser, H., Müller, J., Jouzel, J., and Johnsen, S.: The cold event 8200 years ago documented in oxygen isotope records of precipitation in Europe and Greenland, Clim. Dynam., 14, 73-81, 1998.

von Grafenstein, U., Erlenkeuser, H., Brauer, A., Jouzel, J., and Johnsen, S. J.: A mid-European decadal isotope-climate record 
from 15,500 to 5000 years BP, Science, 284, 1654-1657, 1999. von Kamp, H. and Ribbert, K.-H.: Erläuterungen zu Blatt 4611 Hagen-Hohenlimburg Geologische Karte von NordrheinWestfalen 1:25.000, Krefeld, 2005.

Wackerbarth, A., Scholz, D., Fohlmeister, J., and Mangini, A.: Modelling the $\delta^{18} \mathrm{O}$ value of cave drip water and speleothem calcite, Earth Planet. Sc. Lett., 299, 387-397, 2010.

Wanner, H., Beer, J., Bütikofer, J., Crowley, T., Cubasch, U., Flückiger, J., Goosse, H., Grosjean, M., Joos, F., Kaplan, J., Küttel, M., Müller, S. A., Prentice, I. C., Solomina, O., Stocker, T. F., Tarasov, P., Wagner, M., and Widmann, M.: Mid-to late Holocene climate change: An overview, Quaternary Sci. Rev., 27, 1791-1828, 2008.
Wanner, H., Solomina, O., Grosjean, M., Ritz, S. P., and Jetel, M.: Structure and origin of Holocene cold events, Quaternary Sci. Rev., 30, 3109-3123, 2011.

Wurth, G.: Klimagesteuerte Rhythmik in spät-bis postglazialen Stalagmiten des Sauerlandes, der Fränkischen Alb und der Bayerischen Alpen, Ph.D. thesis, Ruhr-Universität Bochum, Universitätsbibliothek, 2002. 